\title{
DESIGN AND OPERATION ANALYSIS OF DRIP IRRIGATION SYSTEMS USED IN THE IRRIGATION OF CHERRY (PRUNUS AVIUM L.) ORCHARDS IN ISPARTA-ULUBORLU REGION, TURKEY
}

\author{
YILDIZ, H. ${ }^{1}-$ KADAYIFCI, A. ${ }^{2 *}$ \\ ${ }^{1}$ Fruit Research Station Directorate, Egirdir-Isparta, Turkey \\ ${ }^{2}$ Faculty of Technology, Suleyman Demirel University, Isparta, Turkey \\ *Corresponding author \\ e-mail: abdullahkadayifci@sdu.edu.tr \\ (Received 29 ${ }^{\text {th }}$ Dec 2017; accepted $1^{\text {st }}$ May 2018)
}

\begin{abstract}
In this study, the existing drip irrigation systems of 20 cherry (Prunus avium L.) orchards in Isparta-Uluborlu (Turkey) region where cherry production is done intensively were evaluated with selected by purposive sampling method; were examined in terms of design and operation; problems related to the subject were determined. For this reason, drip and under tree micro sprinkler irrigation system was re-projected for each enterprise, elements of both irrigation systems compared with the present applications, and suggestions for both irrigation systems and irrigation scheduling are developed. As a result, it has been found that the system elements generally had not been designed properly, and the system layouts and operations were insufficient in all of the existing drip irrigation systems considered. Suggestions for both irrigation systems and irrigation scheduling are developed. Keywords: cherry orchard, Prunus avium L., drip irrigation, under tree micro sprinkler irrigation, irrigation scheduling
\end{abstract}

\section{Introduction}

Almost all new cherry orchards established in Turkey for export are established by the 0900 Agricultural variety of saplings. In general, the harvest of the export grade of 0900 Agricultural variety begins in the first week of May in Izmir province the early season and ends in the last days of July in Konya-Hadim and NigdeUlukisla districts as the late season (Taner, 2001). Parallel to the developments in cherry exports, cherry production, in many cities begun to increase, in recent years; though leading provinces in cherry production are Izmir, Manisa, Afyon, Bursa, Konya, Amasya, Isparta, and Denizli in Turkey (Table 1; Anonymous, 2016a). Denizli and Izmir are early; other provinces are mid-season cherry production regions.

Isparta province is an important cherry production region for export with highquality mid-season production. It is in the 6th rank in mid-season production regions in terms of yield. In 2016, cherry production was 55657 tons, the total number of trees was 1197822, and average yield per tree was $46 \mathrm{~kg}$. The major cherry producing areas are the districts of Senirkent and Uluborlu (Table 2; Anonymous, $2016 b$ ). Fresh cherries are the leading agricultural product that provides export income for the Isparta province. $60 \%$ of agricultural products in 2007 were provided by cherries. The value of cherry exports was $\$ 5.7$ million in $2005, \$ 7.9$ million in 2006, and amounted to $\$ 10.14$ million in 2007 (Anonymous, 2009a). 


$$
-3132-
$$

Table 1. Data of leading provinces in cherry production in Turkey

\begin{tabular}{c|c|c|c|c}
\hline Province in Turkey & $\begin{array}{c}\text { Area of collective } \\
\text { fruit trees (ha) }\end{array}$ & $\begin{array}{c}\text { Total fruit } \\
\text { yield (t) }\end{array}$ & $\begin{array}{c}\text { Fruit yield per tree } \\
\left.\text { (kg tree }^{-1}\right)\end{array}$ & $\begin{array}{c}\text { Total number of } \\
\text { trees }\end{array}$ \\
\hline Izmir & 12097 & 46574 & 15 & 3033963 \\
Manisa & 9886 & 46648 & 20 & 2325630 \\
Afyon & 4215 & 403387 & 63 & 645942 \\
Bursa & 6250 & 32468 & 23 & 1435434 \\
Konya & 6664 & 55426 & 33 & 1662921 \\
Amasya & 2529 & 25008 & 34 & 739425 \\
Isparta & 5427 & 55657 & 46 & 1197822 \\
Denizli & 3787 & 22695 & 33 & 686015 \\
Nigde & 2519 & 23386 & 46 & 507116 \\
Kutahya & 2769 & 35152 & 28 & 1235223 \\
Others regions & 28603 & 216249 & 24 & 7784421 \\
\hline Turkey & 84745 & 599650 & 25 & 21313912 \\
\hline
\end{tabular}

Table 2. Distribution of Isparta cherry production according to districts

\begin{tabular}{c|c|c|c|c}
\hline District & $\begin{array}{c}\text { Area of collective } \\
\text { fruit trees (ha) }\end{array}$ & $\begin{array}{c}\text { Total fruit yield } \\
(\mathbf{t})\end{array}$ & $\begin{array}{c}\text { Fruit yield per } \\
\text { tree }\left(\mathbf{k g ~ t r e e}^{-1}\right)\end{array}$ & $\begin{array}{c}\text { Total number of } \\
\text { trees (number) }\end{array}$ \\
\hline Center & 675 & 6993 & 30 & 149100 \\
Aksu & 7 & 48 & 42 & 1452 \\
Atabey & 300 & 1720 & 25 & 61120 \\
Egirdir & 61 & 375 & 35 & 11435 \\
Gelendost & 54 & 4188 & 35 & 89300 \\
Gonen & 140 & 603 & 35 & 64265 \\
Keciborlu & 226 & 910 & 33 & 44100 \\
Senirkent & 1750 & 22700 & 33 & 302500 \\
Sutculer & 31 & 274 & 35 & 11670 \\
Sarkikaraagac & 175 & 1157 & 30 & 45700 \\
Uluborlu & 1760 & 14905 & 33 & 353100 \\
Yalvac & 172 & 961 & 30 & 41000 \\
Yenisarbademli & 75 & 823 & 35 & 23080 \\
\hline Isparta & 5427 & 55657 & 46 & 1197822 \\
\hline
\end{tabular}

It is expected that the climate changes expected to occur as a result of global warming will have adverse effects on water resources as well as agricultural production. Depending on the expected changes in climate, such as temperature, precipitation, relative humidity and wind, the water consumption of the plant, which is important in terms of irrigation, and the feeding of the groundwater also change, and those affect the water resources negatively (Anonymous, 1995). In addition to the problems of climate change and drought that may be experienced in relation to this, rapid population 
increase, increase in demand for water resources, the tendency of water usage to change gradually according to sectors, decrease in the water quality, and so on increase the importance of the utilization of water resources. According to the results of the assessment made by the World Meteorological Organization (WMO) among 87 member countries, Turkey is among the 74 countries affected by drought (WMO, 1992).

It is possible to predict the pressure over water resources occurred by the impacts of factors such as current growth rate and change of water consumption habits. Therefore, it is necessary to use water resources rationally to leave for healthy and sufficient water to the future generations of Turkey. This means the utilization of water should be planned and in the most efficient way.

In Turkey, both the consciousness and education levels of producers and excessive irregularity of irrigation studies and extreme and faulty water use due to the problems in transferring the results of those studies to the producers have negative effects on soil, environment, plants and water resources in particular. It was found in a study conducted in Sanliurfa-Harran irrigation that about 5 to 7 times of the needed water was supplied to irrigation and that the groundwater levels were higher than $150 \mathrm{~cm}$, which is considered as the threshold of danger (Tekinel et al., 2001).

Turkey is the first sweet cherry producer cherry production with 494000 tons of sweet cherry a year (Anonymous, 2009b). Isparta-Uluborlu region has an important place in our country in terms of production quantity and product quality. In recent years cherry producers have started to prefer drip irrigation instead of surface irrigation methods. However, these orchards, which are established on the basis of traditional farming, are experiencing problems in designing and operating drip irrigation systems which are subsequently constructed.

In studies conducted to monitor and evaluate the existing drip irrigation systems. It was observed that farmers had generally preferred the drip irrigation system with low initial capital cost, thus planning, layout and operation of a system had been unsuitable and water distribution had not been uniform required. It was also found that drippers had rapidly clogged due to inconvenient filtration and poor water quality (Pitchford, 1979; Fry, 1985). In a few research to evaluate some drip irrigation systems in Turkey (Turkey), the system elements had not been designed properly, the filtration of irrigation water to prevent emitter clogging had not been supplied by installing an adequate control head, and the system layouts and operations were insufficient in all drip irrigation systems considered nine farms in the Antalya region (Yildirim and Orta, 1993), and it also found that drip irrigation systems were not projected as suitable according to project criteria, sufficient control unity was not established, excessive irrigation water was applied and planning and managing of the systems were not done as suitable with regard to current conditions in Sultanhisar and Eskisehir region (Ayran, 2009; Harman, 2013).

In this study, the existing drip irrigation systems of 20 cherry (Prunus avium L.) orchards in Isparta-Uluborlu (Turkey) region where cherry production is done intensively were evaluated with selected by purposive sampling method; were examined in terms of design and operation; problems related to the subject were determined. For this reason, drip and under tree micro sprinkler irrigation system was re-projected for each enterprise. Elements of both irrigation systems compared with the present applications. And suggestions for both irrigation systems and irrigation scheduling are developed. 


\section{Materials and methods}

The research was carried out in 20 cherry (Prunus avium L.) orchards in IspartaUluborlu (Turkey) region (Fig. 1), selected by purposive sampling method, among the enterprises where drip irrigation method is applied.
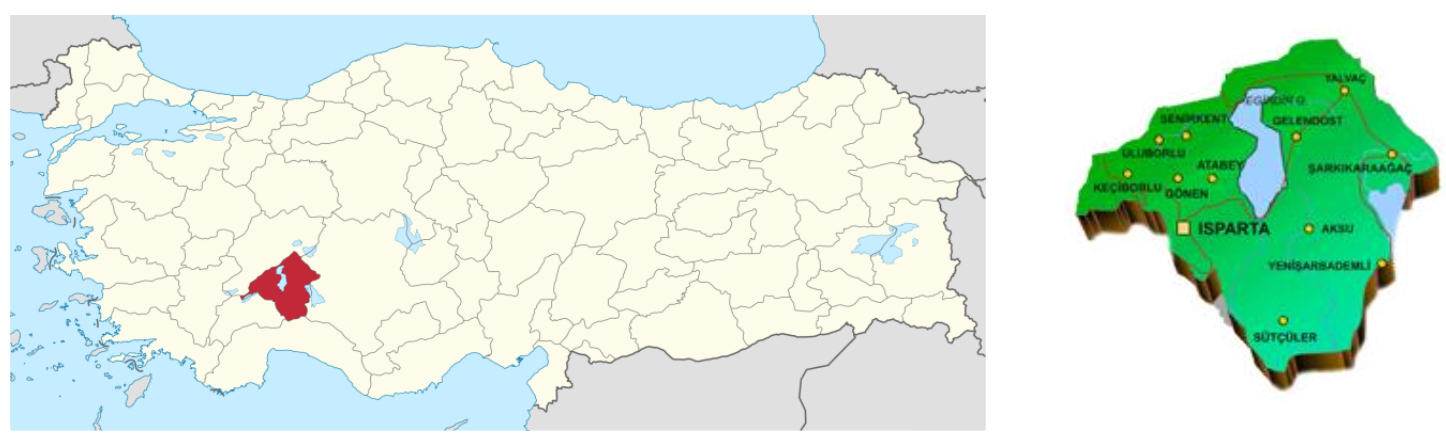

Figure 1. The placement of Isparta and Uluborlu in Turkey

During the research, a survey study was conducted primarily to determine the existing irrigation application skills and levels of the selected producers. The characteristics of the existing irrigation systems in all enterprises (dripper flow and distance, lateral pipe diameter and length, number of lateral pipes running in a row and to be supplied water at the same time, manifold pipe diameter and length, main pipe diameter and length, pipe materials) and control unit factors (filter system, gravel filters, hydro cyclone, sieve-disc filter, pressure regulator, fertilizer tank volume, manometer, valve etc.), were determined according to the measurements and observations conducted.

However, for all enterprises, the data that is essential for project design of the drip and micro sprinkler irrigation method has been obtained. For this purpose, some important characteristics of the enterprise's soil (texture class, field capacity, wilting point and volume weights) for irrigation was determined according to Demiralay (1993) and Tuzuner (1990). Deteriorated and intact soil samples were taken from different layers $(0-30,30-60,60-90$ and $90-120 \mathrm{~cm})$ from the test site. The infiltration rates of the soil of the test area were determined according to the principles given by Gungor and Yildirim (1989) with double cylinder infiltrometer measurements. The dimensions of the enterprise areas were measured by steel tape meters and slopes with the aid of a leveling instrument. The flow rate of the water source was measured by the volumetime method and the sufficiency for cultivation was examined.

In order to determine the irrigation water needs of the cherry plants cultivated in the examined enterprises, firstly the values of the plant water consumption are determined. Climate data of the region where the enterprises are located were taken from Isparta Meteorology Directorate and the values of plant water consumption were determined by the Penman-Monteith method for the process in plant vegetation period. For this, tenday-long average values of the climate data between 1990 and 2010 were taken into account (Table 3; Anonymous, 2011), the reference plant water consumption was calculated, and actual plant water consumption values are obtained by correcting the obtained values with the plant coefficient. Plant coefficients were calculated according to a previous study (Evans et al., 1996). 
Yildiz - Kadayifci: Design and operation analysis of drip irrigation systems used in the irrigation of cherry (Prunus avium L.) orchards in Isparta-Uluborlu region, Turkey

$$
-3135-
$$

Table 3. Some climatic values of Uluborlu District, including a ten-day long average

\begin{tabular}{c|c|c|c|c|c}
\hline Date & $\begin{array}{c}\text { Average steam } \\
\text { pressure }(\mathbf{h} \text { Pa) }\end{array}$ & $\begin{array}{c}\text { Average } \\
\text { temperature }\left({ }^{\circ} \mathbf{C}\right)\end{array}$ & $\begin{array}{c}\text { Average wind } \\
\text { speed }\left(\mathbf{m ~ s}^{-1}\right)\end{array}$ & $\begin{array}{c}\text { Average relative } \\
\text { humidity }(\boldsymbol{\%})\end{array}$ & $\begin{array}{c}\text { Sunrise time } \\
(\mathbf{h})\end{array}$ \\
\hline 01-10 May & 898.66 & 13.7 & 2.75 & 56.30 & 9.60 \\
11-20 May & 899.43 & 15.7 & 2.33 & 52.46 & 9.60 \\
21-31 May & 898.48 & 17.5 & 2.49 & 55.99 & 9.40 \\
01-10 June & 898.97 & 18.4 & 2.50 & 55.24 & 9.60 \\
11-20 June & 898.78 & 20.2 & 2.41 & 51.11 & 11.30 \\
21-30 June & 898.34 & 21.4 & 2.50 & 49.41 & 11.00 \\
01-10 July & 897.10 & 22.7 & 2.32 & 47.46 & 11.30 \\
11-20 July & 897.64 & 23.0 & 2.35 & 49.19 & 11.30 \\
21-31 July & 896.76 & 23.3 & 2.45 & 46.77 & 11.60 \\
01-10 August & 896.25 & 23.5 & 2.35 & 49.26 & 11.20 \\
11-20 August & 897.64 & 23.1 & 1.93 & 48.25 & 11.10 \\
21-31 August & 898.37 & 21.6 & 1.83 & 48.19 & 10.90 \\
01-10 Sept & 899.23 & 18.8 & 1.91 & 52.90 & 9.90 \\
11-20 Sept & 900.18 & 17.7 & 1.90 & 53.55 & 9.30 \\
21-30 Sept & 900.99 & 15.9 & 2.28 & 60.54 & 8.20 \\
01-10 Oct & 901.92 & 14.9 & 2.25 & 59.75 & 8.00 \\
11-20 Oct & 902.00 & 13.3 & 2.37 & 64.14 & 6.20 \\
21-31 Oct & 902.37 & 10.5 & 2.33 & 66.57 & 6.20 \\
\hline
\end{tabular}

For each enterprise, a re-drip and under micro sprinkler irrigation system has been designed. In determining the engineering characteristics of the system, the principles given in Yildirim (2008) were utilized. The equations used for the under tree micro sprinkler irrigation system's project design are summarized below.

Wetted area $(\mathrm{P})$

$$
\mathrm{P}=\frac{\alpha^{-}}{360^{\circ}} \frac{\pi \mathrm{D}^{2}}{4 \mathrm{~S}_{\mathrm{a}} \mathrm{S}_{\mathrm{s}}}
$$

Heading wetting diameter (D)

$$
\begin{array}{ll}
D=\sqrt{\frac{2604 S_{z} S_{z} 0,30}{x_{z}}} & \text { for } P=0.30 \\
D=\sqrt{\frac{2604 S_{z} S_{z} 0,50}{x_{\pi}}} & \text { for } P=0.50
\end{array}
$$

Precipitating rate $\left(\operatorname{Pr}_{\mathrm{y}}\right)$

$$
\operatorname{Pr}_{y}=\frac{360^{\circ}}{\propto} \frac{4 \mathrm{q}}{\pi \mathrm{D}^{2}}
$$




$$
\text { - } 3136 \text { - }
$$

Evapotranspiration for micro irrigation methods $(\mathrm{T})$

$$
\mathrm{T}=\mathrm{ET} \frac{P s}{95}
$$

Amount of maximum net irrigation water $\left(\mathrm{d}_{\mathrm{n}} \max \right)$

$$
\mathrm{d}_{\mathrm{n}} \max =\mathrm{d}_{\mathrm{k}} \operatorname{Ry} \mathrm{D} \frac{\mathrm{p}}{100}
$$

Amount of total irrigation water $\left(\mathrm{d}_{\mathrm{t}}\right)$

$$
d_{t}=\frac{d_{n}}{E_{a}}
$$

Maximum irrigation interval $\left(\mathrm{SA}_{\max }\right)$

$$
\mathrm{SA}_{\max }=\frac{\mathrm{dn}_{\max }}{\mathrm{T}}
$$

Amount of net irrigation water $\left(d_{n}\right)$

$$
\mathrm{d}_{\mathrm{n}}=\mathrm{T}(\mathrm{SA})
$$

Irrigation duration $(\mathrm{Ta})$

$$
\mathrm{T}_{\mathrm{a}}=\frac{1000 \mathrm{~d}_{\mathrm{t}}}{\mathrm{qN}_{\mathrm{d}}}
$$

Maximum number of operating units $\left(\mathrm{N}_{\max }\right)$

$$
\mathrm{N}_{\max }=\left(\frac{\mathrm{T}_{\mathrm{g}}}{\mathrm{T}_{\mathrm{a}}}\right)(S A)
$$

Reference evapotranspiration for Penman-Monteith method

$$
E T_{0}=\delta /\left(\delta+\gamma^{*}\right)(R n-G) \frac{1}{\lambda}+\gamma /(\delta+\gamma) u^{2}\left(\frac{900}{t+275}\right)\left(e_{a}-e_{d}\right)
$$

where $\mathrm{P}$ is wetted area (\%), D is head wetting diameter $(\mathrm{m}), \mathrm{S}_{\mathrm{a}}$ is tree spacing $(\mathrm{m}), \mathrm{S}_{\mathrm{s}}$ is row spacing $(\mathrm{m}), \mathrm{Pr}_{\mathrm{y}}$ is precipitating rate $\left(\mathrm{mm} \mathrm{h}^{-1}\right), \alpha$ is wetting angle, $\mathrm{q}$ is head flow $\left(1 \mathrm{~h}^{-1}\right), \mathrm{T}$ is evapotranspiration for micro sprinkler irrigation method (mm day $\left.{ }^{-1}\right)$, ET is evapotranspiration $\left(\mathrm{mm}\right.$ day $\left.^{-1}\right)$, Ps is ratio of the area shaded by the plant to the total area $(\%), d_{n} \max$ is amount of maximum net irrigation water $(\mathrm{mm}), \mathrm{d}_{\mathrm{k}}$ is available water holding capacity $(\mathrm{mm} / \mathrm{m})$, Ry is allowable part of $d_{k}$, D is watering soil depth $(\mathrm{mm}), \mathrm{Ea}$ is water application efficiency (\%), $\mathrm{SA}_{\max }$ is maximum water application interval (days), SA is irrigation interval (days), $T_{a}$ is irrigation duration (h), $d_{t}$ is amount of total 


$$
\text { - } 3137 \text { - }
$$

irrigation water $(\mathrm{mm}), \mathrm{N}_{\mathrm{d}}$ is number of head in a decare area (pieces da ${ }^{-1}$ ), $\mathrm{N}_{\max }$ is maximum number of operating units, $\mathrm{T}_{\mathrm{g}}$ is daily irrigation duration $\left(\mathrm{h} \mathrm{day}^{-1}\right), \mathrm{ET}_{\mathrm{o}}$ is reference evapotranspiration $\left(\mathrm{mm} \mathrm{day}^{-1}\right), \delta$ is slope of the vapor pressure curve $\left(\mathrm{kPa}^{\circ} \mathrm{C}^{-}\right.$ $\left.{ }^{1}\right), \gamma^{*}$ is modified psychometric constant $\left(\mathrm{kPa} /{ }^{\circ} \mathrm{C}\right), \mathrm{Rn}$ is net radiation on the plant surface $\left(\mathrm{MJ} \mathrm{m}^{-2}\right.$ day $\left.^{-1}\right), \mathrm{G}$ is heat flow in the ground $\left(\mathrm{MJ} \mathrm{m}^{-2}\right.$ day $\left.^{-1}\right), \lambda$ is evaporation latent heat $\left(\mathrm{MJ} / \mathrm{kg}^{-1}\right), \mathrm{u}^{2}$ is equivalent of wind speed at $2 \mathrm{~m}$ height $\left(\mathrm{m} \mathrm{s}^{-1}\right), \mathrm{t}$ is average temperature $\left({ }^{\circ} \mathrm{C}\right), \mathrm{e}_{\mathrm{a}}$ is saturated vapor pressure at average air temperature $(\mathrm{kPa})$ and $\mathrm{e}_{\mathrm{d}}$ is actual vapor pressure at average air temperature $(\mathrm{kPa})$ in Equations 1-12.

\section{Results and discussion}

The average values of soil texture, field capacity, wilting point, volume weight and available water holding capacity of the soil samples taken from the enterprises obtained from the physical analyzes and the values of infiltration rate measured by the double cylinder infiltrometer are given in Table 4. The soil texture class was generally clayey, loamy and sandy-loamy and the infiltration rate values of the enterprise's soil ranged from $6.5 \mathrm{~mm} / \mathrm{h}$ to $18.1 \mathrm{~mm} / \mathrm{h}$.

Table 4. Some physical properties of the enterprise's soil

\begin{tabular}{|c|c|c|c|c|c|c|}
\hline $\begin{array}{l}\text { Orchard } \\
\text { number }\end{array}$ & $\begin{array}{l}\text { Soil texture } \\
\text { class }\end{array}$ & $\begin{array}{l}\text { Infiltration } \\
\text { rate }\left(\mathrm{mm} \mathrm{h}^{-1}\right)\end{array}$ & $\begin{array}{c}\text { Field } \\
\text { capacity }(\%)\end{array}$ & $\begin{array}{c}\text { Wilting } \\
\text { point }(\%)\end{array}$ & $\begin{array}{c}\text { Volume } \\
\text { weight }\left(\mathrm{g} \mathrm{cm}^{-3}\right)\end{array}$ & $\begin{array}{c}\text { Available water } \\
\text { holding capacity } \\
\left.\text { (mm } 120 \mathrm{~cm}^{-1}\right)\end{array}$ \\
\hline 1 & $\mathrm{~L}$ & 12.4 & 26.10 & 12.32 & 1.40 & 230.68 \\
\hline 2 & $\mathrm{SL}$ & 18.1 & 18.99 & 8.58 & 1.49 & 185.51 \\
\hline 3 & L, SL & 13.0 & 22.14 & 11.88 & 1.58 & 194.84 \\
\hline 4 & L, CL, SICL & 9.0 & 28.53 & 18.48 & 1.64 & 197.48 \\
\hline 5 & L, SIL & 10.6 & 25.92 & 13.53 & 1.49 & 220.79 \\
\hline 6 & $\mathrm{SL}$ & 16.0 & 18.81 & 9.02 & 1.53 & 179.74 \\
\hline 7 & $\mathrm{~L}$ & 12.5 & 26.55 & 12.76 & 1.40 & 230.84 \\
\hline 8 & $\mathrm{CL}$ & 6.9 & 31.68 & 22.44 & 1.69 & 187.39 \\
\hline 9 & $\mathrm{CL}$ & 7.0 & 29.79 & 20.79 & 1.78 & 192.51 \\
\hline 10 & $\mathrm{~L}$ & 11.0 & 26.19 & 13.64 & 1.46 & 219.50 \\
\hline 11 & $\mathrm{~L}, \mathrm{SCL}$ & 10.8 & 27.36 & 16.17 & 1.45 & 194.71 \\
\hline 12 & $\mathrm{~L}$ & 12.0 & 25.65 & 12.65 & 1.44 & 223.25 \\
\hline 13 & $\mathrm{C}, \mathrm{CL}$ & 6.5 & 27.99 & 19.80 & 1.85 & 181.33 \\
\hline 14 & SCL, C & 9.0 & 27.90 & 19.14 & 1.81 & 190.27 \\
\hline 15 & $\mathrm{~L}$ & 12.0 & 24.84 & 12.65 & 1.43 & 209.55 \\
\hline 16 & L, SICL & 9.5 & 26.10 & 12.98 & 1.40 & 220.81 \\
\hline 17 & SL & 17.0 & 21.06 & 9.35 & 1.26 & 177.06 \\
\hline 18 & $\mathrm{CL}$ & 7.0 & 29.34 & 20.13 & 1.76 & 193.96 \\
\hline 19 & $\mathrm{SL}, \mathrm{CL}$ & 14.0 & 22.68 & 9.79 & 1.35 & 208.82 \\
\hline 20 & SL & 16.0 & 21.87 & 11.11 & 1.42 & 183.67 \\
\hline
\end{tabular}

C: clayey, L: loamy, SL: sandy loam, SCL: sandy clayey loam, SICL: silt clayey loam, SIL: silt loam

The results of the survey study to determine the existing irrigation application skills and levels of the producers of cherry farming in the enterprises and the factors of the 


$$
\text { - } 3138 \text { - }
$$

existing drip irrigation systems in the enterprises (dripper flow and distance, lateral pipe diameter and length, number of lateral pipes running in a row and to be supplied water at the same at the same time, manifold pipe diameter and length, main pipe diameter and length, pipe materials, etc.) and the results of measurements and observations made on the elements of the control unit (filter system, gravel filter, hydro cyclone, sieve-disk filter, pressure regulator, volume of fertilizer tank, manometer, valve etc.) are given in Table 5.

Table 5. Features of the existing drip irrigation systems in enterprises

\begin{tabular}{|c|c|c|c|c|c|c|c|c|c|c|c|c|c|c|c|c|c|c|c|c|}
\hline \multirow{2}{*}{$\begin{array}{l}\text { Irrigation system } \\
\text { parameters }\end{array}$} & \multicolumn{20}{|c|}{ Enterprise number } \\
\hline & 1 & 2 & 3 & 4 & 5 & 6 & 7 & 8 & 9 & 10 & 11 & 12 & 13 & 14 & 15 & 16 & 17 & 18 & 19 & 20 \\
\hline Area (ha) & 1.0 & 0.23 & 4.8 & 0.5 & 0.95 & 0.95 & 4.8 & 1.45 & 0.47 & 1.45 & 1.0 & 3.3 & 0.63 & 2.0 & 0.63 & 0.9 & 2.9 & 0.55 & 1.05 & 2.4 \\
\hline Tree distance $(\mathrm{m})$ & 8 & 8 & 7 & 5 & 5 & 8 & 6 & 6 & 6 & 7 & 7 & 8 & 6 & 7 & 7 & 7 & 5 & 5 & 7 & 7 \\
\hline Row distance (m) & 8 & 9 & 6 & 10 & 8 & 6 & 6 & 5 & 6 & 7 & 7 & 8 & 6 & 7 & 7 & 7 & 3 & 3 & 6.5 & 6 \\
\hline Land slope (\%) & 0.1 & 0.5 & 0.1 & 1 & 0.1 & 4 & 1.5 & 2 & 5 & 2 & 0.5 & 0.5 & 0.5 & 1.5 & 2 & 3.5 & 2 & 1 & 0.2 & 4 \\
\hline $\begin{array}{l}\text { Fertilizer tank volume } \\
\text { (l) }\end{array}$ & 50 & - & 150 & 50 & - & 100 & 100 & 50 & 50 & 50 & 100 & 50 & 50 & 50 & 100 & 100 & 100 & 50 & 50 & 50 \\
\hline Filter & + & - & + & + & + & - & + & + & + & + & - & + & - & + & + & + & + & + & + & + \\
\hline Main pipe material & PE & PE & PVC & PE & $\mathrm{PE}$ & PVC & $\mathrm{PVC}$ & $\mathrm{PVC}$ & $\mathrm{PE}$ & PE & PE & $\mathrm{PVC}$ & $\mathrm{PE}$ & PVC & PE & $\mathrm{PE}$ & PE & $\mathrm{PE}$ & $\mathrm{PVC}$ & PVC-PE \\
\hline $\begin{array}{l}\text { Main pipe diameter } \\
(\mathrm{mm})\end{array}$ & 75 & 75 & 110 & 75 & 75 & 110 & 110 & 110 & 90 & 90 & 90 & 110 & 90 & 110 & 90 & 90 & 90 & 90 & 110 & $75-110$ \\
\hline Main pipe length (m) & 50 & 55 & 120 & 50 & 50 & 85 & 240 & 0 & 65 & 105 & 100 & 223 & 45 & 88 & 150 & 152 & 225 & 145 & 109 & 246 \\
\hline $\begin{array}{l}\text { Manifold pipe } \\
\text { diameter }(\mathrm{mm})\end{array}$ & 75 & 50 & 110 & 50 & 63 & 75 & 90 & 90 & 50 & 63 & 63 & $63-110$ & $63-90$ & $75-110$ & 75 & 63 & $50-90$ & 90 & 90 & 75 \\
\hline $\begin{array}{l}\text { Manifold pipe length } \\
\text { (m) }\end{array}$ & 65 & 42 & 110 & 50 & 50 & $75-110$ & 200 & 110 & 110 & 70 & 200 & 416 & 75 & 190 & 50 & 50 & $55-145$ & 48 & 115 & 77 \\
\hline $\begin{array}{l}\text { Lateral pipe diameter } \\
(\mathrm{mm})\end{array}$ & 16 & 16 & 20 & 16 & 16 & 16 & 16 & 16 & 16 & 16 & 16 & 16 & 16 & 16 & 20 & 16 & 16 & 16 & 16 & 16 \\
\hline Lateral pipe length (m) & 75 & 56 & 282 & 50 & 100 & 60 & 30 & 100 & 50 & 50 & 50 & $48-100$ & 55 & 63 & 75 & 45 & 45 & $45-62$ & 40 & $42-78$ \\
\hline $\begin{array}{l}\text { Lateral pipe number of } \\
\text { a tree line (number) }\end{array}$ & 2 & 4 & 2 & 4 & 5 & 4 & 2 & 2 & 2 & 4 & 4 & 4 & 4 & 4 & 4 & 4 & 2 & 4 & 4 & 2 \\
\hline Dripper range $(\mathrm{m})$ & 0.5 & 0.33 & 0.5 & 0.4 & 0.5 & 0.4 & 0.4 & 0.5 & 0.2 & 0.5 & 0.5 & 0.33 & 0.5 & 0.5 & 0.4 & 0.5 & 0.4 & 0.4 & 0.5 & 0.33 \\
\hline Operating pressure $(\mathrm{m})$ & 15 & 15 & 18 & 18 & 15 & 15 & 18 & 12 & 12 & 15 & 10 & 15 & 20 & 10 & 10 & 15 & 20 & 20 & 25 & 20 \\
\hline Dripper flow $\left(1 \mathrm{~h}^{-1}\right)$ & 2 & 3 & 2 & 2 & 2 & 2.4 & 2 & 2.2 & 2 & 4 & 4 & 4 & 3 & 4 & 2 & 1.6 & 2 & 2 & 4 & 2 \\
\hline $\begin{array}{l}\text { Irrigation interval } \\
\text { (days) }\end{array}$ & 7 & 7 & 10 & 8 & 5 & 8 & 7 & 7 & 15 & 15 & - & 7 & 7 & 12 & 7 & 7 & 8 & 7 & 7 & 5 \\
\hline Irrigation duration (h) & 6 & 13 & 12 & 12 & 6 & 12 & 24 & 12 & 8 & 8 & 8 & 10 & 6 & 8 & 10 & 7 & 12 & 10 & 10 & 9 \\
\hline $\begin{array}{l}\text { Applied irrigation } \\
\text { water amount (mm) }\end{array}$ & 45.9 & 95.9 & 13.5 & 126 & 220 & 19.5 & 59.3 & 37.8 & 432.1 & 21 & 32.5 & 88.8 & 31.5 & 28.6 & 56 & 139.9 & 104.4 & 172.3 & 113.6 & 82.4 \\
\hline Wetted area $(\%)$ & 15 & 26 & 17 & 38 & 60 & 24 & 16 & 20 & 8 & 34 & 34 & 20 & 40 & 34 & 35 & 34 & 19 & 38 & 34 & 11 \\
\hline
\end{tabular}

As can be seen from Table 5, the enterprises participated in the research have a size ranging from 0.23 to 4.8 ha. Eleven of the enterprises (55\%) are small ( $<1.0$ ha) family businesses. Operation flows in almost all of the enterprises are sufficient to allow the irrigation systems work efficiently.

It has been determined that the diameters of the main pipes used in the twelve enterprises $(60 \%)$ in the research $(1,2,7,8,9,10,13,14,15,16,18$ and 19) are oversized. This situation increases the initial installation costs of the systems. In addition, in three enterprises $(15 \%)(3,5$ and 11$)$ the employed main pipe diameters were less than the required value. Side pipe diameters are larger than the required values in twelve enterprises $(60 \%)(1,2,7,8,12,13,15,16,17,18$ and 20) and smaller in seven enterprises $(35 \%)$.

It was stated that if the wetted area percentage (p) is less than $30 \%$, in the case of using two laterals for each tree row in the irrigation of the fruit trees according to the 
drafting criteria of the drip irrigation system project, a micro-sprinkler system for this area will be more suitable (Anonymous, 2011). Seven of the farms (35\%) surveyed in the research had two lateral laid along each plant row, but the wetted areas did not reach the desired level in any of them. In the other thirteen enterprises $(65 \%)$, irrigation is carried out by 4-5 laterals laid along each tree row. In this case, the cost of the first installation of the irrigation system increases, as well as problems in terms of management occurs. However, in the nineteenth of the enterprises (95\%) (except for the operation of 15) the lateral pipe diameters are in required ranges.

Besides, there is no problem in the operation of the irrigation system except for the 3rd enterprise. However, there is a problem in the operation of the irrigation system in the 3rd enterprise. Sufficient amount of irrigation water in sufficient time to apply the appropriate irrigation program to the enterprises located in the area where this enterprise is also located, cannot be supplied by the legal entity with the duty of operating the water mains. The infrastructure of the irrigation system has not been set up properly to provide enough water for agricultural land. It is not believed that the dispute between the company, which established the irrigation system that is located here, and the legal entity of the village can be resolved by the courts, either.

In the examined cherry orchards, the plant row spacing ranges from 5 to $8 \mathrm{~m}$. Dripper spacing ranges from 0.2 to $0.5 \mathrm{~m}$ between the laterals used in existing irrigation systems. Therefore, 4-5 laterals in each plant row should be laid in order to obtain a sufficient level of wetting in the root area of the plant. a sufficient wetting zone in the plant root area cannot be established in 50\% of the enterprises surveyed. The irrigation interval is longer than necessary for all enterprises except the 5th and 20th (90\%). In other words, irrigation practices are not done in the form required by the drip irrigation. As is known, the plant root area is kept moist at the appropriate level by giving a little water at short intervals by drip irrigation method. In addition to this, although the irrigation duration is favorable in four enterprises $(20 \%)(1,4,12$ and 13), more irrigation periods are being implemented in ten enterprises $(50 \%)(2,3,6,7,8,14,15$, 17, 19 and 20), which in turn, causes excess irrigation water to be used in the mentioned enterprises. In the other six enterprises $(30 \%)(5,9,10,11,16$ and 18), less irrigation water is given to the plants because of the less irrigation time applied.

Similar to this research findings, in a few research to evaluate some drip irrigation systems in Turkey (Turkey), the system elements had not been designed properly according to project criteria (Ayran, 2009; Harman, 2013), the filtration of irrigation water to prevent emitter clogging had not been supplied by installing an adequate control head, and the system layouts and operations were insufficient in all considered drip irrigation systems (Yildirim and Orta, 1993).

While Table 6 gives information on irrigation systems that are re-projected, considering the characteristics of soil, plant and water resources for each enterprise examined whereas the recommended irrigation scheduling at the meetings held with the producer is summarized in Table 7. Moreover, the hypothetical irrigation scheduling to be applied if the irrigation was continued with the existing irrigation system in the enterprises is given in Table 8.

It was suggested that in the pressurized system; the main pipeline should be constructed from PVC pipes and the manifold pipelines from PE pipes while the T pipelines should be installed as buried in the ground (Kekec, 2006; Yilmaz, 2011). And it was concluded that it would be more appropriate to place the control unit at a single point and at the start of the main pipeline for easier operation in micro irrigation 


$$
-3140-
$$

systems and it would be more appropriate to place the required sand separator and sandgravel filter tank at the beginning of the water distribution network in the case of collective micro-irrigation systems. Also, the control unit elements in individual irrigation systems in each operation should be formed of the fertilizer tank, sieve filter, and pressure regulator, if necessary (Yildirim, 2008). In the project of the reconstructed irrigation system for the surveyed enterprises, the main and manifold pipelines were designed according to the principles proposed by Kekec (2006) and Yilmaz (2011) whereas mass irrigation system and selected control unit elements (except pressure regulator) for individual gardens were made according to the principles recommended by Yildirim (2008). The possibility of applying drip irrigation method for each enterprise unit in the survey was examined by taking the principles given in Yildirim (2008) into account. Since the plant and soil characteristics of the enterprises do not allow the installation of the drip irrigation system by laying two laterals along each plant row, it is decided that the more suitable irrigation method for the operators is under tree micro-sprinkler irrigation and the proposed irrigation system is designed accordingly.

Table 6. The parameter of under tree micro sprinkler irrigation systems

\begin{tabular}{|c|c|c|c|c|c|c|c|c|c|c|c|c|c|c|c|c|c|c|c|c|}
\hline \multirow{2}{*}{$\begin{array}{l}\text { Irrigation system } \\
\text { parameters }\end{array}$} & \multicolumn{20}{|c|}{ Enterprise number } \\
\hline & 1 & 2 & 3 & 4 & 5 & 6 & 7 & 8 & 9 & 10 & 11 & 12 & 13 & 14 & 15 & 16 & 17 & 18 & 19 & 20 \\
\hline Head flow $\left(1 \mathrm{~h}^{-1}\right)$ & 160 & 300 & 40 & 200 & 160 & 160 & 200 & 90 & 90 & 200 & 200 & 250 & 90 & 160 & 200 & 160 & 100 & 100 & 200 & 200 \\
\hline $\begin{array}{l}\text { Head wetting diameter } \\
(\mathrm{m})\end{array}$ & 6.5 & 7 & 5 & 5.5 & 5 & 5.5 & 5 & 4.5 & 4.5 & 5.5 & 5.5 & 6.5 & 6.5 & 5.5 & 5.5 & 5.5 & 3 & 3 & 5 & 5 \\
\hline $\begin{array}{l}\text { Number of operating } \\
\text { unit }\end{array}$ & 1 & 1 & 3 & 1 & 1 & 1 & 2 & 1 & 1 & 1 & 1 & 2 & 1 & 1 & 1 & 1 & 3 & 1 & 1 & 3 \\
\hline Lateral pipe length (m) & 75 & 56 & 50 & 50 & 50 & 60 & 60 & $65-70$ & 50 & 50 & 50 & 56 & 55 & 63 & 75 & 70 & $25-90$ & $45-62$ & 62.5 & $48-60$ \\
\hline $\begin{array}{l}\text { Lateral pipe diameter } \\
(\mathrm{mm})\end{array}$ & 20 & 25 & 16 & 16 & 16 & 20 & 25 & 16 & 16 & 25 & 25 & 20 & 16 & 25 & 25 & 20 & $20-25$ & 16 & 20 & 20 \\
\hline $\begin{array}{l}\text { Manifold pipe length } \\
(\mathrm{m})\end{array}$ & 65 & 42 & $75-90$ & 50 & 100 & 72 & $66-67$ & 100 & 110 & 70 & 200 & 80 & 75 & 190 & 50 & 50 & $65-125$ & 48 & 80 & 77 \\
\hline $\begin{array}{l}\text { Manifold pipe } \\
\text { diameter }(\mathrm{m})\end{array}$ & 75 & 63 & $50-63$ & 75 & 75 & 75 & 75 & 75 & 63 & 75 & 110 & 63 & 63 & 90 & 90 & 50 & 75 & 50 & 90 & $90-110$ \\
\hline $\begin{array}{l}\text { Number of operating } \\
\text { unit to be supplied at } \\
\text { the same time }\end{array}$ & 1 & 1 & 1 & 1 & 1 & 1 & 3 & 1 & 1 & 1 & 1 & 2 & 1 & 1 & 1 & 1 & 2 & 1 & 1 & 1 \\
\hline $\begin{array}{l}\text { Main pipe diameter } \\
(\mathrm{mm})\end{array}$ & 75 & 63 & 90 & 75 & 75 & 75 & 110 & 75 & 90 & 75 & 110 & $90-110$ & 75 & 110 & 90 & 75 & $90-110$ & 48 & 62.5 & 264 \\
\hline Wetted area (\%) & 46 & 47 & 41 & 47 & 43 & 42 & 48 & 47 & 39 & 43 & 43 & 46 & 39 & 43 & 43 & 43 & 41 & 41 & 38 & 41 \\
\hline
\end{tabular}

Table 7. Irrigation scheduling for the under tree micro sprinkler irrigation systems

\begin{tabular}{|c|c|c|c|c|c|c|c|c|c|c|c|c|c|c|c|}
\hline \multirow{2}{*}{$\begin{array}{c}\text { Enterprise } \\
\text { number }\end{array}$} & \multicolumn{3}{|c|}{ May } & \multicolumn{3}{|c|}{ June } & \multicolumn{3}{|c|}{ July } & \multicolumn{3}{|c|}{ Augustus } & \multicolumn{3}{|c|}{ September } \\
\hline & $\begin{array}{l}\text { Ta } \\
\text { (h) }\end{array}$ & $\begin{array}{c}\text { SA } \\
\text { (days) }\end{array}$ & $\begin{array}{c}\mathrm{dt} \\
(\mathbf{m m})\end{array}$ & $\begin{array}{l}\text { Ta } \\
\text { (h) }\end{array}$ & $\begin{array}{c}\text { SA } \\
\text { (days) }\end{array}$ & $\begin{array}{c}\mathbf{d t} \\
(\mathbf{m m})\end{array}$ & $\begin{array}{l}\text { Ta } \\
\text { (h) }\end{array}$ & $\begin{array}{c}\text { SA } \\
\text { (days) }\end{array}$ & $\begin{array}{c}\mathbf{d t} \\
(\mathbf{m m})\end{array}$ & $\begin{array}{l}\text { Ta } \\
\text { (h) }\end{array}$ & $\underset{\text { (days) }}{\text { SA }}$ & $\begin{array}{c}\mathbf{d t} \\
(\mathbf{m m})\end{array}$ & $\begin{array}{l}\text { Ta } \\
\text { (h) }\end{array}$ & $\begin{array}{c}\text { SA } \\
\text { (days) }\end{array}$ & $\begin{array}{c}\mathrm{dt} \\
(\mathrm{mm})\end{array}$ \\
\hline 1 & 10.5 & 10 & 56.7 & 10.6 & 6 & 57.5 & 9.0 & 4 & 48.9 & 10.6 & 4 & 57.2 & 10.9 & 12 & 58.9 \\
\hline 2 & 5.2 & 8 & 45.4 & 5.5 & 5 & 47.9 & 5.6 & 4 & 48.9 & 4.9 & 3 & 42.9 & 5.6 & 10 & 49.1 \\
\hline 3 & 4.5 & 9 & 51.3 & 4.2 & 5 & 47.9 & 4.3 & 4 & 48.9 & 3.7 & 3 & 42.9 & 4.3 & 10 & 49.1 \\
\hline 4 & 6.3 & 9 & 53.1 & 5.7 & 5 & 47.9 & 5.8 & 4 & 48.9 & 5.1 & 3 & 42.9 & 5.8 & 10 & 49.1 \\
\hline 5 & 5.6 & 9 & 51.0 & 5.2 & 5 & 47.9 & 5.3 & 4 & 48.9 & 4.7 & 3 & 42.9 & 5.9 & 11 & 54.0 \\
\hline 6 & 5.1 & 7 & 39.7 & 4.9 & 4 & 38.3 & 4.7 & 3 & 36.7 & 5.5 & 3 & 42.9 & 5.0 & 8 & 39.2 \\
\hline 7 & 5.6 & 11 & 63.3 & 5.0 & 6 & 57.5 & 5.4 & 5 & 61.1 & 5.0 & 4 & 57.2 & 5.2 & 12 & 58.9 \\
\hline 8 & 7.1 & 8 & 45.4 & 7.5 & 5 & 47.9 & 7.7 & 4 & 48.9 & 6.8 & 3 & 42.9 & 7.7 & 10 & 49.1 \\
\hline 9 & 6.7 & 7 & 42.9 & 9.0 & 6 & 57.5 & 5.8 & 3 & 36.7 & 6.7 & 5 & 42.9 & 6.2 & 8 & 39.2 \\
\hline 10 & 5.4 & 9 & 51.0 & 5.1 & 5 & 47.9 & 5.2 & 4 & 48.9 & 4.5 & 3 & 42.9 & 5.2 & 10 & 49.1 \\
\hline 11 & 5.0 & 8 & 47.8 & 4.0 & 4 & 38.3 & 3.9 & 3 & 36.7 & 4.5 & 3 & 42.9 & 4.7 & 9 & 44.2 \\
\hline 12 & 6.9 & 10 & 58.7 & 6.8 & 6 & 57.5 & 5.8 & 4 & 48.9 & 6.8 & 4 & 57.2 & 6.4 & 11 & 54.0 \\
\hline
\end{tabular}




$$
-3141 \text { - }
$$

\begin{tabular}{l|l|l|l|l|l|l|l|l|l|l|l|l|l|l|l|l}
13 & 6.4 & 8 & 40.4 & 6.0 & 4 & 38.3 & 5.8 & 3 & 36.7 & 4.5 & 2 & 28.6 & 6.2 & 8 & 39.2 \\
14 & 6.2 & 8 & 46.7 & 5.1 & 4 & 38.3 & 4.9 & 3 & 36.7 & 5.7 & 3 & 42.9 & 5.9 & 9 & 44.2 \\
15 & 9.0 & 9 & 51.0 & 8.4 & 5 & 47.9 & 8.6 & 4 & 48.9 & 7.6 & 3 & 42.9 & 9.5 & 11 & 54.0 \\
16 & 6.8 & 9 & 51.0 & 6.4 & 5 & 47.9 & 6.5 & 4 & 48.9 & 5.7 & 3 & 42.9 & 7.2 & 11 & 54.0 \\
17 & 2.6 & 7 & 41.5 & 2.4 & 4 & 38.3 & 2.3 & 3 & 36.7 & 1.8 & 2 & 28.6 & 2.5 & 8 & 39.2 \\
18 & 7.9 & 8 & 45.4 & 6.7 & 4 & 38.3 & 6.4 & 3 & 36.7 & 7.5 & 3 & 42.9 & 7.7 & 9 & 44.2 \\
19 & 3.5 & 7 & 39.7 & 3.4 & 4 & 38.3 & 3.2 & 3 & 36.7 & 3.8 & 3 & 42.9 & 3.9 & 9 & 44.2 \\
20 & 3.5 & 7 & 39.7 & 3.4 & 4 & 38.3 & 3.2 & 3 & 36.7 & 3.8 & 3 & 42.9 & 3.4 & 8 & 39.2 \\
\hline
\end{tabular}

Ta: irrigation duration; SA: irrigation interval; dt: amount of total irrigation water

Table 8. Irrigation scheduling for the existing irrigation systems

\begin{tabular}{|c|c|c|c|c|c|c|c|c|c|c|c|c|c|c|c|}
\hline \multirow{2}{*}{$\begin{array}{l}\text { Enterprise } \\
\text { number }\end{array}$} & \multicolumn{3}{|c|}{ May } & \multicolumn{3}{|c|}{ June } & \multicolumn{3}{|c|}{ July } & \multicolumn{3}{|c|}{ Augustus } & \multicolumn{3}{|c|}{ September } \\
\hline & $\begin{array}{l}\text { Ta } \\
\text { (h) }\end{array}$ & \begin{tabular}{|c|} 
SA \\
(days)
\end{tabular} & $\begin{array}{c}\mathbf{d t} \\
(\mathbf{m m})\end{array}$ & $\begin{array}{l}\text { Ta } \\
\text { (h) }\end{array}$ & \begin{tabular}{|c|} 
SA \\
(days)
\end{tabular} & $\begin{array}{c}\mathrm{dt} \\
(\mathrm{mm})\end{array}$ & $\begin{array}{l}\text { Ta } \\
\text { (h) }\end{array}$ & \begin{tabular}{|c|} 
SA \\
$($ days $)$
\end{tabular} & $\begin{array}{c}\mathrm{dt} \\
(\mathrm{mm})\end{array}$ & Ta $(h)$ & \begin{tabular}{|c|} 
SA \\
(days)
\end{tabular} & $\begin{array}{c}\mathbf{d t} \\
(\mathbf{m m})\end{array}$ & \begin{tabular}{l|} 
Ta \\
(h)
\end{tabular} & \begin{tabular}{|c|}
$\begin{array}{c}\text { SA } \\
(\text { days })\end{array}$ \\
\end{tabular} & $\begin{array}{c}\mathrm{dt} \\
(\mathbf{m m})\end{array}$ \\
\hline 1 & 8 & 10 & 45 & 8 & 5 & 45 & 8 & 4 & 45 & 10.6 & 5 & 45 & 8 & \begin{tabular}{|l|}
10 \\
\end{tabular} & 45 \\
\hline 2 & 7 & 20 & 110 & 7 & 15 & 110 & 7 & 12 & 110 & 7 & 12 & 110 & 7 & 15 & 110 \\
\hline 3 & 8.2 & 12 & 57.5 & 8.2 & 6 & 57.5 & 8.2 & $5-6$ & 57.5 & 8.2 & 7 & 57.5 & 8.2 & 10 & 57.5 \\
\hline 4 & 5.5 & 12 & 58 & 5.5 & 6 & 58 & 5.5 & 5 & 58 & 5.5 & 5 & 58 & 5.5 & 12 & 58 \\
\hline 5 & 7.2 & 9 & 43.3 & 7.2 & 5 & 43.3 & 7.2 & 4 & 43.3 & 7.2 & 5 & 43.3 & 7.2 & 9 & 43.3 \\
\hline 6 & 5 & 12 & 52.9 & 5 & 7 & 52.9 & 5 & 5 & 52.9 & 5 & 8 & 52.9 & 5 & 13 & 52.9 \\
\hline 7 & 7 & 14 & 67.9 & 7 & 7 & 67.9 & 7 & 7 & 67.9 & 7 & 9 & 67.9 & 7 & 14 & 67.9 \\
\hline 8 & 5.5 & 13 & 55.2 & 5.5 & 7 & 55.2 & 5.5 & 6 & 55.2 & 5.5 & 7 & 55.2 & 5.5 & 10 & 55.2 \\
\hline 9 & 2.5 & 28 & 113.2 & 2.5 & 15 & 113.2 & 2.5 & 11 & 113.2 & 2.5 & 19 & 113.2 & 2.2 & 24 & 113.2 \\
\hline 10 & 7.5 & 9 & 43 & 7.5 & 5 & 43 & 7.5 & $4-5$ & 43 & 7.5 & 6 & 43 & 7.5 & 9 & 43 \\
\hline 11 & 5 & 7 & 57.3 & 5 & 6 & 57.3 & 5 & 6 & 57.3 & 5 & 7 & 57.3 & 5 & 12 & 57.3 \\
\hline 12 & $6-6.5$ & 14 & 65.7 & $6-6.5$ & 9 & 65.7 & $6-6.5$ & 6 & 65.7 & $6-6.5$ & 8 & 65.7 & $6-6.5$ & 14 & 65.7 \\
\hline 13 & 9.3 & 12 & 53.4 & 9.3 & 6 & 53.4 & 9.3 & 5 & 53.4 & 9.3 & 7 & 53.4 & 9.3 & 9 & 53.4 \\
\hline 14 & 10 & 13 & 56 & 10 & $6-7$ & 56 & 10 & $5-6$ & 56 & 10 & 6 & 56 & 10 & 9 & 56 \\
\hline 15 & 6 & 12 & 61.6 & 6 & 7 & 61.6 & 6 & 6 & 61.6 & 6 & 8 & 61.6 & 6 & 11 & 61.6 \\
\hline 16 & 9.2 & 9 & 65 & 9.2 & 5 & 65 & 9.2 & 4 & 65 & 9.2 & 6 & 65 & 9.2 & 10 & 65 \\
\hline 17 & 5 & 12 & 52.1 & 5 & $5-6$ & 52.1 & 5 & $5-6$ & 52.1 & 5 & 6 & 52.1 & 5 & 15 & 52.1 \\
\hline 18 & 8.5 & 7 & 57 & 8.5 & $6-7$ & 57 & 8.5 & 5 & 57 & 8.5 & 8 & 57 & 8.5 & 14 & 57 \\
\hline 19 & 5.5 & 13 & 61.4 & 5.5 & 7 & 61.4 & 5.5 & $5-6$ & 61.4 & 5.5 & $7-8$ & 61.4 & 5.5 & $8-9$ & 61.4 \\
\hline 20 & 3.5 & 12 & 54 & 3.5 & 6 & 54 & 3.5 & 6 & 54 & 3.5 & 7 & 54 & 3.5 & 10 & 54 \\
\hline
\end{tabular}

Ta: irrigation duration; SA: irrigation interval; dt: amount of total irrigation water

\section{Conclusion}

As a result, if it is desired to receive the expected benefits and an increase in the irrigation application efficiency from irrigation systems in the enterprise; the importance of assigning the design and construction of the drip irrigation systems, which require knowledge and experience, to professionals, and to firms with the required expertise has been stated.

During the design of the irrigation systems projects, the soil characteristics of the enterprise (texture, field capacity, wilting point, volume weight, available water holding capacity texture, infiltration rate etc); plant characteristics (characteristics of rootstocks and root systems used, planting distances, development and yield of trees, etc.), and characteristics of water resources (flow, quality etc) should be taken into account; designing the project for each enterprise must be done individually, and specific to the enterprise. 
After the irrigation system in the enterprises has been designed and installed in accordance with the criteria mentioned above; training of the operators on the operation of the irrigation system to by experts, and the necessity to apply the appropriate irrigation program considering the climate values of the regions where the enterprises are located, should be provided.

Acknowledgments. This study has been supported by the Suleyman Demirel University Scientific Research Projects Coordination Unit within the scope of the project number 3149-YL-12. We would like to thank the Suleyman Demirel University Scientific Research Projects Coordination Unit Directorate for their support.

Conflict of interest. The author confirms that this article content has no conflict of interest.

\section{REFERENCES}

[1] Anonymous (1995): Irrigation techniques of irrigated crops in Turkey. - General Directorate of Rural Services, APK Office Directorate of Soil and Water Resources Research Department, Public. no: 89, Menemen.

[2] Anonymous (2009a): http://www.fao.org. - Access date: January 12, 2013.

[3] Anonymous (2009b): http://www.fao.org. - Access date: January 3, 2016.

[4] Anonymous (2011): Records of the General Directorate of State Meteorology. http://www.dmi.gov.tr. Access date: November 10, 2011.

[5] Anonymous (2016a): Turkish Statistical Institute. - http://www.rapor.tuik.gov.tr. Access date: March 14, 2016.

[6] Anonymous (2016b): Turkish Statistical Institute. - http://www.rapor.tuik.gov.tr. Access date: March 14, 2016.

[7] Ayran, Y. (2009): A study on observation of drip irrigation systems used in strawberry gardens in Sultanhisar region. - M.Sc. Thesis, Adnan Menderes Univ. Graduate School of Natural and Applied Sciences, Aydin.

[8] Demiralay, I. (1993): Soil Physical Analysis. - Ataturk University Publications No.143, Erzurum.

[9] Evans, R. G., Proebsting, E. L., Mahan, M. O. (1996): Daily furrow irrigation in orchards. Vol. 6(2). - American Society of Agricultural Engineers. http://www.prsurge.com/orchard.htm.

[10] Fry, R. A. (1985): Trickle system evaluation findings in the San Joaquin Valley, California. - Drip/Trickle Irrigation in Action 1: 288-293.

[11] Gungor, Y., Yildirim, O. (1989): Field Irrigation Systems. - Ankara University, Faculty of Agriculture, Public. no. 1155, Ankara.

[12] Harman, E. (2013): A study on observation of drip irrigation systems used in tomato cultivation in Eskisehir region. - M.Sc. Thesis, Suleyman Demirel Univ. Graduate School of Natural and Applied Sciences, Isparta.

[13] Kekec, U. (2006): Determination of root distribution in slaughtered sowing plant citrus irrigated with drip irrigation method. - M.Sc. Thesis, Cukurova University, Graduate School of Natural and Applied Sciences, Adana.

[14] Pitchford, J. (1979): Drip system emission uniformity evaluation by mathematical model. - ASAE, Paper No: 79-2098, 23.

[15] Taner, Y. (2001): Determination of marketing policies and strategies of cherry poultry exports. - I. Hard Core Fruits Symposium, Yalova.

[16] Tekinel, O., Kanber, R., Unlu, M., Topaloglu, F. (2001): Salinity problem in SanliurfaHarran irrigation and precautions. - 1st National Irrigation Congress, Antalya. 
[17] Tuzuner, A. (1990): Soil and Water Analysis Laboratories Handbook. - General Directorate of Rural Services, Ankara.

[18] WMO (1992): Monitoring, Assessment and Combat of Drought and Desertification. WMO/TD-No.505, Geneva

[19] Yildirim, O. (2008): Design of Irrigation Systems. - Ankara University, Faculty of Agriculture, Public. no: 1565, Textbook No.518, Ankara.

[20] Yildirim, O., Orta, H. (1993): Evaluation of some drip irrigation systems in Antalya region. - Tr. J. of Agricultural and Forestry 17: 499-509.

[21] Yilmaz, C. I. (2011): Effect of different irrigation strategies applied by drip irrigation method on yield and water utilization efficiency of winter and summer chickpea plants. M.Sc. Thesis, Cukurova University, Graduate School of Natural and Applied Sciences, Adana. 